Nataša Rupčič**

Marijana Jakopič Ganič**
JEL Classification: M12, M52, M53

Preliminary statement

https://doi.org/10.32910/ep.72.1.2

\title{
CAREER DEVELOPMENT AND LEARNING AS DEMOTIVATORS IN LARGE COMPANIES OF PRIMORJE-GORSKI KOTAR COUNTY, CROATIA
}

In this paper, aspects of the human resource management: motivation, career management and management of learning have been analyzed on the sample of the largest companies in Primorje-Gorski kotar (PGK) county. In this research, career management has been explored through the prism of employee motivation, while a special emphasis was given to learning, which could enable long term employability and career development of employees in their current or organizations of their future employment. The questionnaire was designed on the basis of the presented literature review and sent to a total of 20 largest companies in PGK county based on the report by the Croatian economic chamber, County chamber Rijeka. Even though the sample was small, which is its main limitation, this research pointed to several deficiencies in human resource management. Despite different expectations, the results have shown that large companies in this county dedicate only average attention to all three examined human resource management aspects. The most striking finding is the fact that managers of the surveyed companies do not frequently resort to non-material rewards that are easily available and show appreciation to employees. This fact contributes to below average satisfaction of employees with motivation programs, as expressed by managers. It is promising that the surveyed companies invest above aver-

* N. Rupčić, PhD, Full Professor, University of Rijeka, Faculty of Economics and Business (e-mail: natasa.rupcic@efri.hr).

** M. Jakopič Ganić,PhD candidate, Polytechnic of Rijeka (e-mail:mjakopic@ veleri.hr).The paper was received on 18.02.2019. It was accepted for publication on 08.05.2019. 
N. RUPČIĆ, M. JAKOPIČ GANIĆ: Career development and learning as demotivators in large companies of Primorje-Gorski... EKONOMSKI PREGLED, 72 (1) 34-58 (2021)

age efforts in the introduction of new learning programs due to significant changes in business conditions. Weak and negative correlation among the surveyed constructs and business results points to possible deepening of current problems and gloomy forecasts regarding further development of this county. These results could further exacerbate the already devastating emigration and brain drain problem in Croatia.

Keywords: human resources, motivation, career management, learning

\section{INTRODUCTION}

Many Croatian companies continuously report weak business results when compared to their foreign counterparts. It is important to explore causes of such outcomes and suggest solutions for identified problems considering modern business trends. Modern management connotes a high level of proactivity, balance between focus and flexibility, openness to new perspectives, prompt reaction to opportunities, development based on integration of differences followed by continuous and systematic individual and organizational learning (Rupčić, 2018, p. 1). Successful business could therefore thrive on active engagement of human resources as the key factor that contributes to the creation and development of the value added.

Studies in the field of human resource management are often focused on analyzing motivation and satisfaction of employees. By studying these aspects in the Republic of Croatia, Brnad, Stilin and Tomljenović (2016) found "job security" to be the strongest motivator for Croatian employees, while "regularity of pay" was

found to be the factor with which Croatian employees showed the greatest level of satisfaction. These results point to the conclusion of relatively unfavorable business conditions in Croatia since these factors are not even motivators according to the Herzberg's two-factor theory. In addition, this research revealed that employees expressed the greatest dissatisfaction with the factor of "promotion possibility".

By examining non-material compensations among employees of the so-called generation Y (individuals born from 1980s to the late 1990s), Šandrk Nukić (2017) found that members of this generation considered non-material rewards generally important. However, the greatest importance was given to career development, which entails a higher level of authority and responsibility. In addition, in was found that members of this generation also valued the factor of work security as well as mentoring as an opportunity for learning and development of their knowledge and skills.

These and other research results indicate that the process of career management in Croatian enterprises is generally problematic. For that reason, in this 
research, career management was analyzed on the sample of 20 largest companies in PGK county, Croatia. In this research, career management has been explored through the prism of employee motivation. Aware of the importance of ensuring their long-term employability, employees continuously look for opportunities for learning and knowledge development. In modern business, knowledge is the key to promotion and further career development and it increases labor market mobility and long-term employability (Maurer, 2011). In addition, modern work requires continuous learning. For this reason, in this research, a special emphasis was given to learning, which could enable career development of employees in their current or organizations of their future employment.

\section{REVIEW OF KEY AREAS OF HUMAN RESOURCE MANAGEMENT}

\subsection{Employee motivation}

When making decisions regarding employee motivation, management could adopt two different approaches or their combination. One approach is based on external or extrinsic outcomes such as material rewards while the other is based on internal or intrinsic outcomes such as approval or recognition that provoke feelings of belonging, respect, satisfaction due to accomplishment etc. (Algorta and Zeballos, 2011). Motivation approaches generally refer to rewards and recognition, which are often considered synonyms (Hansen, Smith and Hanson, 2002). Reward given as a raise could be considered a form of recognition. However, in order to fully benefit from their effects, these categories should be considered separately and used in combination. Pratheepkanth (2011) found that employees who received recognition for their work exhibited a higher level of self-esteem, were more prone to accepting challenging assignments and more frequently resorted to creative and innovative behavior.

Research in the Greek public sector showed that extrinsic rewards were awarded more often, though it was found that intrinsic recognition had a greater influence on results (Manolopoulos, 2007). However, research showed that material factors, especially the level of salary, were not equally important to all individuals in all situations (Rynes, Gerhart and Minette, 2004). DeGieter and Hofmans (2015) examined preferences of employees in Belgian financial institutions toward extrinsic and intrinsic rewards and concluded that workforce fluctuation was indirectly related to the level of satisfaction with intrinsic factors, while performance 
N. RUPČIĆ, M. JAKOPIČ GANIĆ: Career development and learning as demotivators in large companies of Primorje-Gorski... EKONOMSKI PREGLED, 72 (1) 34-58 (2021)

was influenced by the satisfaction with extrinsic factors, especially financial rewards. When choosing motivation methods and techniques, it is important to match corporate possibilities with the needs of employees. It is recommended that employees are included in the assessment process (Kim, 2006). Previous research revealed that employee characteristics such as demographic profile and capabilities could be crucial factors that determine their motivation preferences (Manolopoulos, 2007).

Importance of motivation in modern business seems greater than ever. For instance, it was determined that motivation was very important in the process of organizational learning which resulted in the higher quality of service, with motivation acting as the mediator (Hays and Hill, 2001). In addition, intrinsic motivation was found to strongly support knowledge exchange, while extrinsic motivation was found to have no effect (Martín Cruz, Martin Pérez and Trevilla Cantero, 2009). However, it should be noted that this research was conducted in a Spanish non-profit organization. It is well-known that people join these organizations for intrinsic and not material reasons.

Non-material factors can have a strong influence on motivation. In their research, Burr and Cordery (2001) found a strong direct connection between application of skills and motivation and work satisfaction. Management should therefore also put a strong emphasis on the process of employee learning and development in order to achieve the synergistic effect of superior performance and work satisfaction and motivation. There are different approaches to motivating and encouraging employee learning. For instance, Kohn (1993) believes that employees should not be rewarded for learning. He approaches learning from the standpoint of employee desire for improvement versus the need imposed by workplace requirements.

\subsection{Career management}

Career is traditionally defined as the process of promoting employees to levels of higher authority and responsibility, which also includes changes in values, attitudes and motivation (Marušić, 2006). In dynamic business conditions, it is useful to introduce alternative career development possibilities such as job rotation, mentoring, increase in job variety (job enlargement), increase in both variety and responsibility (job enrichment), as well as flexible working hours (Kirk, Downey, Duckett and Woody, 2000). The reason lies in the fact that individuals often do not develop a high level of identification with corporate goals and focus instead on their own development and career management. 
With the increase in work experience, employees generally seek higher levels of work freedom and responsibility, which could be ensured by applying previously mentioned methods. However, that process can only be based on the wide employee knowledge base, pointing to the importance of mentoring even for individuals occupying higher hierarchy levels. Mentoring is a process of systematic increase in individual capabilities and performance by carefully exposing individuals to tasks which contain learning opportunities and providing assistance to facilitate learning and implementation of knowledge (Rupčić, 2018, p. 15).

Van Veldhoven and Dorenbosch (2008) found that with the increase in age, the likelihood for employees to receive career development opportunities decreases. However, they also found that with age proactivity of employees increases. This leads to the conclusion that initiatives regarding career development and education could also originate from employees who, regardless of their age, could contribute to the development of their own goals relative to their personal and career development while also contributing to organizational prosperity.

\subsection{Management of learning}

Business risk, uncertainty and ambiguity require continuous learning and implementation of knowledge in the creation of innovative value added (Akgün, Keskin, Byrne, Arena, 2007). The process of work-related learning should therefore be carefully designed and structured. Marušić (2006) identified three levels of work-related learning. The first level refers to training in the context of the current job, the second refers to the enlargement of knowledge for individuals who exceed working standards, while motivated and knowledgeable employees are offered education programs regarding their career development, including skills needed for managerial positions.

In that process, it is very important to determine which forms of learning could result in the increase of motivation and yield best results. Special attention should therefore be given to the preparation of learning programs. It is also useful to determine which circumstances trigger learning and explain to employees how identified contingencies correlate with suggested forms and means of learning. In addition, employees should be made aware of the expected results and effects of the suggested learning programs (Griffin, 2011).

Workplace learning can have different forms, such as formal, informal, incidental or accidental learning (Matthews, 1999). Research conducted on the sample of Canadian accountants revealed that different learning strategies are used in practice but informal learning prevails (Hicks, Bagg, Doyle and Young, 2007). 
N. RUPČIĆ, M. JAKOPIČ GANIĆ: Career development and learning as demotivators in large companies of Primorje-Gorski... EKONOMSKI PREGLED, 72 (1) 34-58 (2021)

Walden, Bryan and Ramlall (2011) also found that more than 50\% of workplace learning is informal in nature. It was also determined that interns tend to use e-learning programs more than managers. Bova and Kroth (2011) found that respondents that belong to the generation $\mathrm{X}$ prefer action and incidental learning even though they are aware of the importance of formal workplace learning. It is therefore important to take into consideration employee social characteristics when designing workplace learning programs.

Learning outside the workplace can be used in combination with tools such as social networks. Social networks enable communication beyond the context of a specific workplace, enterprise or even local environment. Breunig (2016) found that sharing of knowledge and especially problem solving experience in that way is equally efficient and effective as face-to-face communication. This method is especially useful for enterprises operating in different locations and for those cooperating with different stakeholders.

Modern approach to workplace learning points to the importance of personalized learning programs that take into consideration not only workplace requirements but also employee characteristics, since each employee interprets importance and usefulness of information in a different manner (Winch and Ingram, 2002). In that way, such a learning environment has the characteristic of multidimensionality, which means that besides workplace characteristics, learning requirements and learning strategies, it should include factors such as the level of former knowledge and experience, as well as the individual's feelings and the degree of awareness regarding these factors (Camille, 2014).

\section{RESEARCH RESULTS}

Aspects of human resource management: motivation, career management and management of learning have been analyzed on the sample of the largest companies in PGK county. The questionnaire was sent to a total of 20 largest companies based on the report by the Croatian economic chamber, County chamber Rijeka (2016). The questionnaire was sent twice via email followed by telephone calls as reminders to solicit participation in the survey. Eleven completed and valid questionnaires have been returned, indicating a response rate of $55 \%$. Research was anonymous. Questionnaire had 22 questions in total. The first part of the questionnaire referred to general characteristics of the surveyed companies. Questions in the second part of the survey were designed based on the presented literature review and were examined by using the Likert scale (1 being the lowest, 5 being the highest). 
All companies from the sample have been in business for 10 years or more. The majority of them were service oriented (64\%). Slightly more than a half reported domestic market orientation. The majority or $55 \%$ of companies operated in the whole Croatia. The vast majority of companies were privately owned (82\%). The questionnaire was predominantly filled by middle managers (64\%), $28 \%$ respondents occupied top management positions, while only one respondent was the representative of the lower management. $72 \%$ of managers have spent from 10 to 20 or over 20 years in the company in question, which indicated that the respondents had a good overview of business operations, contributing to the credibility of the collected data.

\subsection{Employee motivation}

We start by presenting the results regarding management of employee motivation. We particularly focused on examining the following items: employee participation in the design of motivation programs; degree of providing material rewards such as increase in pay, bonuses and other material rewards; degree of rewarding non-material benefits such as praises, expressions of appreciation, flexible working hours; managerial efforts in the aspect of the job content (creation of challenging tasks, participation in decision-making, stimulation of creativity); followed by the opinion of management regarding employee satisfaction with implemented motivation programs. Internal consistency was determined by calculating reliability coefficient (Cronbach's alpha). This five-item measure showed a high reliability $(\alpha=0.89)$.

In order to examine connectedness among the examined items, we calculated the Pearson's correlation coefficient (Table 1). 
N. RUPČIĆ, M. JAKOPIČ GANIĆ: Career development and learning as demotivators in large companies of Primorje-Gorski... EKONOMSKI PREGLED, 72 (1) 34-58 (2021)

Table 1.

\section{PEARSON'S CORRELATION COEFFICIENT FOR ITEMS OF THE CONSTRUCT EMPLOYEE MOTIVATION $(N=11)$}

\begin{tabular}{|l|l|l|l|l|l|}
\hline & $\mathbf{i 1 1}$ & \multicolumn{1}{|c|}{$\mathbf{i 1 2}$} & \multicolumn{1}{|c|}{$\mathbf{i 1 3}$} & $\mathbf{i 1 4}$ & $\mathbf{i 1 5}$ \\
\hline $\mathbf{i 1 1}$ & 1.0000000 & 0.6154299 & 0.5468333 & 0.7731921 & 0.5238415 \\
\hline $\mathbf{i 1 2}$ & 0.6154299 & 1.0000000 & 0.2356841 & 0.3928776 & 0.5400390 \\
\hline $\mathbf{i 1 3}$ & 0.5468333 & 0.2356841 & 1.0000000 & 0.6753170 & 0.5329745 \\
\hline $\mathbf{i 1 4}$ & 0.7731921 & 0.3928776 & 0.6753170 & 1.0000000 & 0.7267562 \\
\hline $\mathbf{i 1 5}$ & 0.5238415 & 0.5400390 & 0.5329745 & 0.7267562 & 1.0000000 \\
\hline $\mathbf{N = 1 1}$ & \multicolumn{5}{|l|}{} \\
\hline
\end{tabular}

Description of items:

1. il1 - employee participation in the design of motivation programs

2. i12 - degree of providing material rewards

3. $i 13$ - degree of providing non-material rewards

4. il4 - managerial efforts in the aspect of job content

5. i15 - managerial opinion of employee satisfaction with motivation programs

Results presented in Table 1 indicate that a strong correlation exists among a large number of the surveyed items. The strongest correlation was found among the items i11 and i14 (employee participation in the design of motivation programs and managerial efforts in the aspect of the job content). This result is consistent with the other finding: a strong correlation was also detected among managerial efforts in the aspect of the job content (i14) and managerial opinion regarding employee satisfaction with the implemented motivation programs (i15). Managerial efforts in the aspect of the job content are often related to the employee participation in that process. In addition, employee participation in the design of motivation programs often includes interventions in the job content, especially in the situation of limited possibilities of providing material rewards. According to Herzberg's two-factor theory of motivation, interventions in the job content have the greatest motivational effect compared to the factors of the job context, such as pay or material rewards. It could be concluded that employee participation in the design of motivation programs and managerial efforts in the aspect of the job content have effect on employee motivation so management should put special emphasis on these factors, especially if material rewards are limited or unavailable. Greater correlation among the items 112 and 115 compared to the correlation among the items i15 and i13 indicates that material rewards still significantly af- 
fect employee motivation, which is expected in countries with salaries below the European average.

Table 2 presents descriptive statistics for items of the construct employee motivation.

Table 2.

\section{DESCRIPTIVE STATISTICS FOR ITEMS OF THE CONSTRUCT EMPLOYEE MOTIVATION N(11)}

\begin{tabular}{|l|c|c|}
\hline & Mean & $\begin{array}{c}\text { Standard } \\
\text { deviation }\end{array}$ \\
\hline $\begin{array}{l}\text { Employee participation in the design of motivation } \\
\text { programs }\end{array}$ & 3.000000 & 1.60000000 \\
\hline Degree of providing material rewards & 3.000000 & 1.72046505 \\
\hline Degree of providing non-material rewards & 2.272727 & 1.32664992 \\
\hline Managerial efforts in the aspect of job content & 2.909091 & 1.32664992 \\
\hline $\begin{array}{l}\text { Managerial opinion of employee satisfaction with } \\
\text { motivation programs }\end{array}$ & 2.545455 & 1.16619038 \\
\hline
\end{tabular}

Results presented in Table 2 indicate that all surveyed items pertaining to the employee motivation construct showed average or below average representation in the large companies of the PGK county. We found that employees participated in the design of motivation programs to an average degree. Material rewards were provided more frequently than non-material rewards. However, managers invested some more effort in the aspect of the job content even though it was below average. Managers admitted that employee satisfaction with motivation programs was also below average, consistent with previous findings.

It is interesting to note that the results indicated polarization within the sample. For instance, five of the surveyed managers agreed that their employees actively participated in the design of motivation programs. One surveyed manager strongly agreed with this statement. The same number of managers expressed such opinion regarding provision of material rewards. Consistent with this finding, four managers agreed with the statement that they were engaged in the segment of the job content to provoke greater employee motivation. It is interesting to note that only two managers agreed to the fact that non-material rewards were used in their companies, while none of them strongly agreed with this fact. It is also interesting 
N. RUPČIĆ, M. JAKOPIČ GANIĆ: Career development and learning as demotivators in large companies of Primorje-Gorski... EKONOMSKI PREGLED, 72 (1) 34-58 (2021)

to note that only three of the surveyed managers agreed that employees were satisfied with the implemented motivation programs.

Further analysis of the sample polarization indicated that companies which managers reported above-average results did not share the same activity orientation: two of them were production-oriented, two were service-oriented, while one was equally production- and service-oriented. It is beneficial to further analyze their characteristics to determine the reason for their above-average results. General differential characteristics included in this research do not seem to offer the answer to that question. However, with the exception of one company that reported a negative overall performance result (loss) and one service-oriented company with a lower profit per employee, all other companies shared a common characteristic of a relatively high profit per employee. It could be presumed that these companies invested in employee motivation more intensively, which was reflected in the improvement of their efficiency and effectiveness. It is worth noting that the worst results in this aspect were reported by the service-oriented companies.

\subsection{Career management}

Next, we present the results regarding the process of career management in the surveyed companies. In this regard, we particularly focused on examining the following items: career development activities such as job enlargement and job enrichment; intensity of developing programs of education and development related to career management; implementation of systemic employee performance evaluation related to career management; opinion of management regarding employee satisfaction with the implemented programs of career management. This five-item measure also showed a high reliability $(\alpha=0.95)$.

In order to examine connectedness among the examined items, we again calculated the Pearson's correlation coefficient (Table 3). 
Table 3.

\section{PEARSON'S CORRELATION COEFFICIENT FOR ITEMS OF THE CONSTRUCT CAREER MANAGEMENT $(N=11)$}

\begin{tabular}{|l|l|l|l|l|c|}
\hline & $\mathbf{i 1 6}$ & $\mathbf{i 1 7}$ & $\mathbf{i 1 8}$ & $\mathbf{i 1 9}$ & $\mathbf{i 2 0}$ \\
\hline $\mathbf{i 1 6}$ & 1.0000000 & 0.8671100 & 0.8265876 & 0.8690476 & 0.6214996 \\
\hline $\mathbf{i 1 7}$ & 0.8671100 & 1.0000000 & 0.7979611 & 0.9068525 & 0.5736588 \\
\hline $\mathbf{i 1 8}$ & 0.8265876 & 0.7979611 & 1.0000000 & 0.9179691 & 0.6819504 \\
\hline $\mathbf{i 1 9}$ & 0.8690476 & 0.9068525 & 0.9179691 & 1.0000000 & 0.5272031 \\
\hline $\mathbf{i 2 0}$ & 0.6214996 & 0.5736588 & 0.6819504 & 0.5272031 & 1.0000000 \\
\hline $\mathbf{N = 1 1}$ & \multicolumn{5}{|l|}{} \\
\hline
\end{tabular}

Description of items:

1. i16 - job enlargement

2. $i 17$ - job enrichment

3. i18 - programs of education and development related to career management

4. i19 - systemic employee performance evaluation related to career management

5. $i 20$ - opinion of management regarding employee satisfaction with implemented programs of career management

Results presented in Table 3 also show strong correlations among the surveyed items. The strongest correlation was found among the items i17 and i19 or job enrichment and systematic employee performance evaluation related to career management. This finding is expected because job enrichment or empowerment in terms of transfer of authority, responsibility and power from management to employees is possible only if employees possess required knowledge and skills (Rupčić, 2018, p. 56), which should be based on the systematic employee performance evaluation. This in turn leads to further possibilities in career development. High correlation was also recorded between the programs of education and development related to career management (i18) and the systematic employee performance evaluation related to career management (i19), which is also according to expectations. Career development beneficial for both an organization and employees should be based on the development of their skills and expertise.

Further analysis is based on the descriptive statistics for items of the construct career management presented in Table 4. 
N. RUPČIĆ, M. JAKOPIČ GANIĆ: Career development and learning as demotivators in large companies of Primorje-Gorski... EKONOMSKI PREGLED, 72 (1) 34-58 (2021)

Table 4.

\section{DESCRIPTIVE STATISTICS FOR ITEMS OF THE CONSTRUCT CAREER MANAGEMENT N(11)}

\begin{tabular}{|l|c|c|}
\hline & Mean & $\begin{array}{c}\text { Standard } \\
\text { deviation }\end{array}$ \\
\hline Job enlargement & 2.727272 & 0.9797959 \\
\hline Job enrichment & 2.909091 & 1.46969385 \\
\hline $\begin{array}{l}\text { Programs of education and development related to career } \\
\text { management }\end{array}$ & 3.090909 & 1.16619038 \\
\hline $\begin{array}{l}\text { Systemic employee performance evaluation related to } \\
\text { career management }\end{array}$ & 3.090909 & 1.32664992 \\
\hline $\begin{array}{l}\text { Opinion of management regarding employee satisfaction } \\
\text { with implemented programs of career management }\end{array}$ & 3.272727 & 1.16619038 \\
\hline
\end{tabular}

Results shown in Table 4 indicate that managerial efforts regarding career management in large companies of the PGK county were also average or below average. Surprisingly, a little more attention was dedicated to developing knowledge and skills of employees through the programs of job enrichment than job enlargement. Equal but average results were obtained regarding investments in programs of education and development related to career management as well as regarding systemic employee performance evaluation related to career management. However, management thinks that employees show slightly above average satisfaction with the implemented programs of career management.

Polarization within the sample was noticed again. Polarization patterns resembled those for the construct of employee motivation. Two of the surveyed managers strongly agreed that in their companies job enlargement was implemented, while four managers agreed with that statement. Four of the surveyed managers agreed that job enrichment was used in their companies, while only one manager strongly agreed with this statement. Three of the surveyed managers strongly agreed with the statement that programs of education and development in their companies were related to career management, while the same number of managers agreed. Three of the surveyed managers agreed that career management in their companies was based on the systemic employee performance evaluation. Only two of the surveyed managers completely supported this statement. Four of the surveyed managers agreed to the statement that employees in their companies were satisfied with the implemented programs of career management, while one manager strongly agreed. 
Analysis of the sample polarization for this construct showed the same pattern as for the construct of employee motivation. In other words, again, aboveaverage results were reported by two production-oriented companies, two serviceoriented companies, and one with the mixed orientation. Again, with the exception of one company that reported a negative result and one service-oriented company with a lower profit per employee, all other companies shared a common characteristic of a relatively high profit per employee. It could be suggested again that investments in motivation and the development of knowledge and skills for the purpose of career management positively affected efficiency and effectiveness of the surveyed companies, contributing to their good results. Consistent with the findings regarding the previous construct, the worst results were reported by the service-oriented companies.

\subsection{Management of learning}

We present next the results regarding management of learning in the surveyed companies. In this respect, we put special emphasis on examining the following items: efforts regarding continuous learning and upgrading of skills of employees in their current position; efforts in determining future knowledge needs with the purpose to design learning programs; introduction of new learning programs due to significant changes in the business conditions such as changes in technology or working conditions; efforts in developing knowledge and skills by introducing job rotation; efforts in developing knowledge and skills by mentoring. This five-item measure also showed a high reliability $(\alpha=0.89)$.

In order to examine connectedness among the examined items, we again calculated the Pearson's correlation coefficient (Table 5). 
N. RUPČIĆ, M. JAKOPIČ GANIĆ: Career development and learning as demotivators in large companies of Primorje-Gorski... EKONOMSKI PREGLED, 72 (1) 34-58 (2021)

Table 5.

\section{PEARSON'S CORRELATION COEFFICIENT FOR ITEMS OF THE CONSTRUCT MANAGEMENT OF LEARNING (N=11)}

\begin{tabular}{|l|l|l|l|l|c|}
\hline & $\mathbf{i 2 1}$ & $\mathbf{i 2 2}$ & $\mathbf{i 2 3}$ & $\mathbf{i 2 4}$ & $\mathbf{i 2 5}$ \\
\hline $\mathbf{i 2 1}$ & 1.0000000 & 0.8730481 & 0.7621715 & 0.5942661 & 0.6280605 \\
\hline $\mathbf{i 2 2}$ & 0.8730481 & 1.0000000 & 0.7426227 & 0.5352989 & 0.6938998 \\
\hline $\mathbf{i 2 3}$ & 0.7621715 & 0.7426227 & 1.0000000 & 0.5330567 & 0.3792287 \\
\hline $\mathbf{i 2 4}$ & 0.5942661 & 0.5352989 & 0.5330567 & 1.0000000 & 0.4337384 \\
\hline $\mathbf{i 2 5}$ & 0.6280605 & 0.6938998 & 0.3792287 & 0.4337384 & 1.0000000 \\
\hline $\mathbf{N}=11$ & \multicolumn{5}{|l|}{} \\
\hline
\end{tabular}

Description of items:

1. $i 21$ - continuous learning and upgrading of skills of employees in their current position

2. $i 22$ - determination of future knowledge needs with the purpose to design learning programs

3. i23 - new learning programs introduced due to significant changes in business conditions

4. i24 - development of knowledge and skills by job rotation

5. i25 - development of knowledge and skills by mentoring

The results shown in Table 5 mostly imply strong correlations among the surveyed items. The strongest correlation was recorded among the items i21 and i22. Continuous learning and upgrading of skills of employees in their current position was found to be related with the determination of future knowledge needs with the purpose to design learning programs. A strong correlation was also found among the items i21 and i23 so continuous learning and upgrading of employee skills in their current position was found to be related to introducing new learning programs due to significant changes in business conditions.

Further analysis is based on the descriptive statistics for items of the construct management of learning (Table 6). 
Table 6.

\section{DESCRIPTIVE STATISTICS FOR ITEMS OF THE CONSTRUCT MANAGEMENT OF LEARNING N(11)}

\begin{tabular}{|l|c|c|}
\hline & Mean & $\begin{array}{c}\text { Standard } \\
\text { deviation }\end{array}$ \\
\hline $\begin{array}{l}\text { Continuous learning and upgrading of skills of employees } \\
\text { in their current position }\end{array}$ & 3.363636 & 1.72046505 \\
\hline $\begin{array}{l}\text { Determination of future knowledge needs with the purpose } \\
\text { to design learning programs }\end{array}$ & 3.000000 & 1.72046505 \\
\hline $\begin{array}{l}\text { New learning programs introduced due to significant } \\
\text { changes in business conditions }\end{array}$ & 3.727273 & 1.6583124 \\
\hline Development of knowledge and skills by job rotation & 2.727273 & 1.72046505 \\
\hline Development of knowledge and skills by mentoring & 3.272727 & 1.46969385 \\
\hline
\end{tabular}

Results shown in Table 6 indicate that managerial efforts regarding management of learning in the large companies of the PGK county showed the best results, though again average. The greatest result was obtained for the fact that new learning programs are introduced due to significant changes in the business conditions. A slightly above average result was also noted for the fact that learning and skills of employees in their current position are continuously upgraded. An average result was obtained regarding the fact that future knowledge needs are determined. The surveyed companies also dedicate slightly above average efforts to developing knowledge by mentoring, which was shown to be more pronounced than job rotation, which was represented to the below average degree.

Polarization within the sample was present again with similar polarization patterns. Two of the surveyed managers strongly agreed with the statement that their companies invested efforts in continuous learning and upgrading of skills of employees in their current position, while five managers agreed. Only one manager strongly agreed with the statement that their company continuously determined future knowledge needs with the purpose to design new learning programs, while five of the surveyed managers agreed. Three of the surveyed managers fully supported the statement that in their companies new learning programs were introduced due to significant changes in the business conditions such as changes in technology or working conditions, while five of them agreed. Five of the surveyed managers agreed with the statement that in their companies knowledge and skills were developed by job rotation, while three respondents fully supported the statement that knowledge and skills were developed through mentoring. 
N. RUPČIĆ, M. JAKOPIČ GANIĆ: Career development and learning as demotivators in large companies of Primorje-Gorski... EKONOMSKI PREGLED, 72 (1) 34-58 (2021)

With this construct, polarization was even more evident. Above-average results were reported by three production-oriented companies, three service-oriented companies, and one company with the mixed orientation. Contrary to the results regarding the two previous constructs, companies that reported investing greater efforts in management of learning did not share the same characteristics regarding their business results. Some of these companies operated in more propulsive industries, making greater investments in learning expected. However, some companies that reported grimmer results or even losses also invested significantly in learning of their employees. Further research is necessary to determine why significant investments in learning did not result in better business results. It could be speculated that these companies faced adverse environmental factors, which hindered their business development. It is of use to note that the worst results were again reported by the two companies that shared activity orientation - both were service oriented. However, business results were not a common denominator considering the fact that one reported losses and the other above average profits.

\subsection{Relationship between averaged variables and business results}

Responses measuring employee motivation, career management and management of learning were averaged to calculate the construct mean. We proceed next with the analysis of the relationship between averaged variables and business results. Tables 7 and 8 present correlation matrices between averaged variables and business results expressed as revenue per employee and profit/loss per employee.

Table 7.

PEARSON'S CORRELATION COEFFICIENT BETWEEN AVERAGED VARIABLES AND REVENUE/EMPLOYEE $(\mathrm{N}=11)$

\begin{tabular}{|l|c|c|c|c|}
\hline & Learning & $\begin{array}{c}\text { Career } \\
\text { management }\end{array}$ & Motivation & $\begin{array}{c}\text { Revenue/ } \\
\text { employee }\end{array}$ \\
\hline Learning & 1.0000000 & 0.8984858 & 0.9066366 & 0.1713603 \\
\hline Career man. & 0.8984858 & 1.0000000 & 0.9582657 & 0.3822382 \\
\hline Motivation & 0.9066366 & 0.9582657 & 1.0000000 & 0.2453264 \\
\hline Revenue/emp. & 0.1713603 & 0.3822382 & 0.2453264 & 1.0000000 \\
\hline N=11
\end{tabular}


Table 8 .

PEARSON'S CORRELATION COEFFICIENT BETWEEN AVERAGED

VARIABLES AND PROFIT-LOSS/EMPLOYEE $(\mathrm{N}=11)$

\begin{tabular}{|l|c|c|c|c|}
\hline & Learning & Careerman. & Motivation & Profit/empl. \\
\hline Learning & 1.0000000 & 0.8984858 & 0.9066366 & -0.2373843 \\
\hline Careerman. & 0.8984858 & 1.0000000 & 0.9582657 & -0.1530731 \\
\hline Motivation & 0.9066366 & 0.9582657 & 1.0000000 & -0.2032599 \\
\hline Profit/empl. & -0.2373843 & -0.1530731 & -0.2032599 & 1.0000000 \\
\hline N=11
\end{tabular}

Results presented in Table 7 imply that correlations between averaged variables and business results expressed as revenue per employee were positive, though statistically not significant, while the surveyed variables strongly mutually correlated. Results presented in Table 8 showed even worse results: averaged variables negatively correlated with business results expressed as profit per employee. These results are consistent with the previous analyses which showed poor results for all constructs but also a strong sample polarization. Even though the surveyed companies do not compete in especially dynamic industries, changes in the general business environment are still rather fast and require rapid adjustments. Weak and negative correlation among the surveyed constructs and business results indicate possible future problems and a loss of legitimacy relative to the stakeholders' interests of the surveyed companies. Even though the sample was small, the surveyed companies were the largest companies in one of the most developed counties in Croatia, which points to gloomy forecasts regarding the development of this county with further exacerbation of the brain drain problem, among other factors, due to unfavorable human resource development conditions.

\section{DISCUSSION AND CONCLUSION}

The results have shown that the largest companies in the PGK county generally dedicate only average attention to managing motivation of their employees. Provision of non-material rewards showed the worst results of all surveyed items, which was surprising because we investigated how often managers reward their employees with praises, expressions of appreciation and flexible working hours. Considering the fact that employees are rarely shown appreciation in this way, it 
N. RUPČIĆ, M. JAKOPIČ GANIĆ: Career development and learning as demotivators in large companies of Primorje-Gorski... EKONOMSKI PREGLED, 72 (1) 34-58 (2021)

could not be expected that they would be eager to accept challenging assignments and resort to creative and innovative behavior (Pratheepkanth, 2011).

Our results also confirmed the finding by Šandrk Nukić (2017) that material rewards are more frequently used in Croatian companies, though in our case only to an average degree. This finding should be related to the fact that the same result was obtained with regard to the employee participation in the design of motivation programs. For the lack of additional data, we could only speculate that employees value material rewards more and participate in the design of such compensation programs. Even though we lack data for such conclusion, it would be likely because Brnad et al. (2016) found that "job security" and "regularity of pay" are of more importance for Croatian employees. However, our results did not confirm the finding by Brnad, Stilin and Tomljenović (2016) who found that employees are generally only passive observers in their companies. Even though employee participation in the design of motivation programs is average, it could also not be claimed that they play a very active role in that process. The fact that managers expressed the belief that their employees showed only below average satisfaction with the introduced motivation programs only further confirms this conclusion.

Career development can be considered an investment of both individuals and organizations into the long-term employability of individuals and not into the security of their current employment (Stevens, 1996). It was found that large companies in the PGK county invest only average or below average efforts in the career development of their employees. Surprisingly, managers expressed a slightly above average belief that employees are satisfied with the implemented programs of career management. However, in the surveyed companies career management does not seem to be predominantly based on the results of the process of employee learning. Programs of education and development related to career management are organized only to an average degree, followed by learning in the process of job enrichment, which showed even worse results. In addition, employee performance is evaluated with regard to their career management only to an average degree. That is why it is not quite clear what the basis for career management in the surveyed companies is, which calls for further investigation.

Career management could be improved by a greater engagement of functional managers (Garavan, 1990). It was found that leadership that encourages employee empowerment positively affects their intrinsic motivation, which strengthens their creative engagement (Zhang and Bartol, 2017). It should be noted that the lack of efforts in career management was found to be a leading cause of dissatisfaction of employees and their high fluctuation and turnover (Davis, 2015). With open borders and more lucrative options abroad, it is likely that vague and non-transparent career management coupled with low motivation contributes to the mass exodus of the Croatian population. 
Dynamic business conditions nowadays do not guarantee long-term separate existence under current business assumptions. Thus, a new form of moral contract between employers and employees should be established (Rowland, 1996). There is often an implicit agreement between employees and employers by which employees are given opportunities for learning and development consistent with their area of expertise, which increases employment possibilities in other organizations and ensures their long-term employability. Such programs thus also serve as compensation mechanisms. In addition, it should be noted that a strong and direct relation was established between employee application of skills and their motivation and work satisfaction (Burr and Cordery, 2001).

Results of this survey showed that large companies in the PGK county invest slightly above average efforts in the management of learning of their employees. It seems that management is aware of significant changes in their business conditions, which could present themselves as opportunities but also threats if they are not followed by an adequate amount of learning. We obtained the highest result for this item, which is promising. However, less attention is dedicated to continuous learning and upgrading of skills of employees in their current position. Even though it could be speculated that the surveyed companies operate in industries in which knowledge quickly becomes obsolete so upgrading of existing knowledge is not important, an overview of the companies in our sample shows that that is not the case. It could be assumed that employee competences in the surveyed companies are primarily based on experience, which was also found to be the case on the sample of employees in SMEs in Finland (Paloniemi, 2006). In this regard, it should be noted that only average attention is dedicated to the determination of future knowledge needs, which further corroborates this conclusion. It is somewhat promising that the surveyed companies recognize the value of mentoring, though only to a slightly more than average degree. In addition, it is surprising that in large companies, which were our target in this research, management uses the benefits of developing knowledge and skills by rotation only to a below average degree.

Despite different expectations, the results have shown that large companies in PGK county do not have significantly pronounced activities in either of the three major human resource aspects - motivation, career management and learning. Our results therefore corroborate previous findings by Pološki Vokić and Grizelj (2007) who, on the sample of Croatian companies, did not find a significant correlation between companies' size and the importance given to education and employee development. In addition, companies in our sample did not belong to propulsive industries. Enterprises in such industries are expected to invest heavily in the development of the human capital. However, in their research, Pološki Vokić and Grizelj (2007) did not detect any correlation between these variables either. 
N. RUPČIĆ, M. JAKOPIČ GANIĆ: Career development and learning as demotivators in large companies of Primorje-Gorski... EKONOMSKI PREGLED, 72 (1) 34-58 (2021)

Even though the sample was small, which is its major drawback, this research pointed to several deficiencies in human resource management, which calls for corrective actions. It could be concluded that the surveyed companies do not pay great attention to the value of their human capital, which is necessary considering rapid changes in the global and local business conditions. It is therefore not reasonable to expect of the surveyed companies to be the motor of growth of this region. Since the development of small and medium sized companies is strongly related to larger corporations, these trends in the human resource management could have negative long-term consequences for the development of entrepreneurship in this region.

Only average investment in motivation and career management could be the reason for greater emigration of employees in search for better options. The surveyed companies were shown to dedicate above average efforts to investments in learning programs due to significant changes in business conditions. However, more lucrative options in the EU could further exacerbate the emigration problem because such investments are not supported by adequate investments in motivation and career management based on learning. It is especially discouraging that management on average does not have the habit to show appreciation to employees by resorting to non-material and hence easily accessible rewards, which is the most common complaint of Croatian employees. In addition, if the surveyed companies were hit by employee fluctuations, they would have to replace missing employees. However, the costs of employment of a new individual could total up to $150 \%$ of the annual salary of the employee that left the organization (Pološki Vokić and Zaninović, 2010), coupled with the loss of skills, knowledge and experience. In addition, organizations that fail to retain their employees were found to experience a decline in customer loyalty and reduction in their goodwill (Chhabra and Mishra, 2008). However, since some of the surveyed companies have shown different results, it could be useful that future studies determine reasons for such dynamics. This research did not provide answers to that questions. However, it was evident that these companies had higher profits per employee. Lastly, it is of benefit to replicate this study on a larger sample in an attempt to reach more generalizable conclusions. 


\section{REFERENCES}

1. Akgün, A. E., Keskin, H., Byrne, J. C., Arena. S. (2007). Emotional and learning capability and their impact on product innovativeness and firm performance. Technovation, 27 (9), September 2007, 501-513. Available at: https:// www.sciencedirect.com/science/article/pii/S016649720700034X

2. Algorta, M, Zeballos, F. (2011). Human resource and knowledge management: best practices identification. Measuring business excellence, 15 (4), 71-80. Available at: https://www.emeraldinsight.com/doi/abs/10.1108/136830 41111184125

3. Bova, B., Kroth, M. (2001). Workplace learning and Generation X. Journal of Workplace Learning, 13 (2), 57-65. Available at: https://www.emeraldinsight. com/doi/abs/10.1108/13665620110383645

4. Breunig, K. J. (2016). Limitless learning: assessing social media use for global workplace learning. The Learning Organization, 23 (4), 249-270. Available at: https://www.emeraldinsight.com/doi/abs/10.1108/TLO-07-2014-0041

5. Brnad, A., Stilin, A., Tomljenović, L. (2016). Istraživanje motivacije i zadovoljstva zaposlenika u Republici Hrvatskoj. Zbornik Veleučilišta u Rijeci, 4 (1), 109-122. Available at: https://hrcak.srce.hr/160237

6. Burr, R., Cordery, J. L. (2001). Self-Management Efficacy as a Mediator of the Relation Between Job Design and Employee Motivation. Human Performance, 14 (1), 27-44. Available at: https://www.tandfonline.com/doi/ abs/10.1207/S15327043HUP1401_03

7. Camille, C. (2014). Workplace learning - a healthcare perspective. Education + Training, 56 (4), 329-342. Available at: https://www.emeraldinsight.com/ doi/abs/10.1108/ET-03-2013-0039

8. Chhabra N. L., Mishra A., (2008). Talent Management and Employer Branding: Retention Battle Strategies. ICFAI Journal of Management Research, 7 (11), 50-61. Available at: https://www.iupindia.in/1108/IJMR_Talent_Management_50.html

9. Croatian Bureau for Statistics / Državni ured za statistiku (2018). Hrvatska u brojkama, Zagreb. Available at: https://www.dzs.hr/Hrv_Eng/CroInFig/croinfig_2018.pdf

10. Croatian economic chamber, County chamber Rijeka / Hrvatska gospodarska komora, Županijska komora Rijeka (2016). Poslovanje poduzetnika Primorsko-goranske županije u 2015. godini (prema godišnjim financijskim izvješćima za 2015. godinu), Rijeka. 
N. RUPČIĆ, M. JAKOPIČ GANIĆ: Career development and learning as demotivators in large companies of Primorje-Gorski... EKONOMSKI PREGLED, 72 (1) 34-58 (2021)

11. Davis, P. J. (2015). Implementing an employee career-development strategy: How to build commitment and retain employees. Human Resource Management International Digest, 23 (4), 28-32. Available at: https://www.emeraldinsight.com/doi/abs/10.1108/HRMID-05-2015-0066?journalCode=hrmid

12. De Gieter, S., Hofmans, J. (2015). How reward satisfaction affects employees' turnover intentions and performance: an individual differences approach. Human Resource Management Journal, 25 (2), 200-216. Available at: https:// onlinelibrary.wiley.com/doi/abs/10.1111/1748-8583.12072

13. Garavan, T.N. (1990). Promoting strategic career development activities: some Irish experience. Industrial and Commercial Training, 22 (6), 22-30. Available at: https://www.emeraldinsight.com/doi/abs/10.1108/EUM0000000001571

14. Griffin, R. P. (2011). Workplace learning evaluation: a conceptual model and framework. Industrial and Commercial Training, 43 (3), 172-178. Available at: https://www.emeraldinsight.com/doi/abs/10.1108/00197851111123631?jou rnalCode $=$ ict

15. Hansen, F., Smith, M., Hanson, R. B. (2002). Rewards and recognition in employee motivation. Compensation \& Benefits Review, 34 (85), 64-72. Available at: https://journals.sagepub.com/doi/abs/10.1177/0886368702034005010

16. Hays, J. M., Hill, A. V. (2001). A preliminary investigation of the relationships between employee motivation/vision, service learning, and perceived service quality. Journal of Operations Management, 19 (3), 335-349. Available at: https://www.sciencedirect.com/science/article/abs/pii/S0272696300000619

17. Hicks, E., Bagg, R., Doyle, W., Young, J. D. (2007). Canadian accountants: examining workplace learning. Journal of Workplace Learning, 19 (2), 61-77. Available at: https://www.emeraldinsight.com/doi/abs/10.1108/ 13665620710728457

18. Kim, D. (2006). Employee Motivation: Just Ask Your Employees. Seoul Journal of Business, 12 (1), 19-35. Available at: http://s-space.snu.ac.kr/handle/10371/1819

19. Kirk, J. J., Downey, B., Duckett, S., Woody, C. (2000). Name your career development intervention. Journal of Workplace Learning, 12 (5), 205-217. Available at: https://www.emeraldinsight.com/doi/abs/10.1108/13665620010316217

20. Kohn, A. (1993). Punished by Rewards. Houghton Mifflin, Boston, MA.

21. Manolopoulos, D. (2007). An evaluation of employee motivation in the extended public sector in Greece. Employee Relations, 30 (1), 63-85. Available at: https://www.emeraldinsight.com/doi/abs/10.1108/01425450810835428

22. Martín Cruz, N., Martín Pérez, V., Trevilla Cantero, C. (2009). The influence of employee motivation on knowledge transfer. Journal of Knowledge Man- 
agement, 13 (6), 478-490. Available at: https:/www.emeraldinsight.com/doi/ abs/10.1108/13673270910997132

23. Marušić, S. (2006). Upravljanje ljudskim potencijalima. ADECO, Zagreb.

24. Matthews, P. (1999). Workplace learning: developing a holistic model. The Learning Organization, 6 (1), 18-29. Available at: https://www.emeraldinsight.com/doi/abs/10.1108/09696479910255684

25. Maurer, Todd J. (2011). Career-relevant learning and development, worker age, and beliefs about self-efficacy for development. Journal of Management, 27 (2), 123-140. Available at: https://journals.sagepub.com/doi/abs/10.1177/ 014920630102700201

26. Paloniemi, S. (2006). Experience, competence and workplace learning. Journal of Workplace Learning, 18 (7/8), 439-450. Available at: https://www.emeraldinsight.com/doi/abs/10.1108/13665620610693006

27. Pološki Vokić, N., Grizelj, H. (2007). Obrazovanje i razvoj zaposlenika u hrvatskim organizacijama. Ekonomski pregled, 58 (12), 851-880. Available at: https://www.researchgate.net/profile/Nina_Poloski_Vokic/publication/ 27203710_OBRAZOVANJE_I_RAZVOJ_ZAPOSLENIKA_U_HRVATSKIM_ORGANIZACIJAMA/links/54f96fa60cf210398e98860a.pdf

28. Pološki Vokić, N., Zaninović, M. (2010). Analiza čimbenika fluktuacije hrvatskih zaposlenika i njihova usporedba s čimbenicima fluktuacije u najrazvijenijim zemljama svijeta. Zbornik Ekonomskog fakulteta u Zagrebu, 8 (2), 25-36. Available at: https://hrcak.srce.hr/70773

29. Pratheepkanth, P. (2011). Reward System and Its Impact on Employee Motivation in Commercial Bank of Sri Lanka Plc. in Jaffna District. Global Journal of Management and Business, 11 (4), 84-92. Available at: https://journalofbusiness.org/index.php/GJMBR/article/view/486

30. Rowland, H. (1996). Whither career development in the NHS?. Health Manpower Management, 22 (3), 13-15. Available at: https://www.emeraldinsight. com/doi/abs/10.1108/09552069610125874

31. Rupčić, N. (2018). Suvremeni menadžment - teorija i praksa. Ekonomski fakultet Sveučilišta u Rijeci, Rijeka.

32. Rynes, S. L., Gerhart, B., Minette, K. A. (2004): The importance of pay in employee motivation: Discrepancies between what people say and what they do. Human Resource Management, 43 (4), 381-394. Available at: https://onlinelibrary.wiley.com/doi/abs/10.1002/hrm.20031

33. Stevens, P. (1996). What works and what does not in career development programmes. Career Development International, 1(1), 11-18. Available at: https:// www.emeraldinsight.com/doi/abs/10.1108/13620439610111372 
N. RUPČIĆ, M. JAKOPIČ GANIĆ: Career development and learning as demotivators in large companies of Primorje-Gorski... EKONOMSKI PREGLED, 72 (1) 34-58 (2021)

34. Šandrk Nukić, I. (2017). Nematerijalno nagrađivanje zaposlenika: očekivanja i preferencije pripadnika generacije Y. Ekonomska misao i praksa, No. 2, prosinac 2017., 637-654. Available at: https://hrcak.srce.hr/index. php?show=clanak\&id_clanak_jezik=282086

35. van Veldhoven, M., Dorenbosch, L. (2008). Age, proactivity and career development. Career Development International, 13 (2), 112-131. Available at: https://www.emeraldinsight.com/doi/abs/10.1108/13620430810860530

36. Walden, P.R., Bryan, V.C., Ramlall, S. (2011). Informal learning in the workplace: a comparison of two models. International Journal of Human Resources Development and Management, 11 (1), 1-15. Available at: https:// www.researchgate.net/profile/Valerie_Bryan2/publication/271516345_ Walden_P_R_Bryan_VC_Rumlall_S_2011_Informal_learning_in_the_ workplace_a_comparison_of_two_models_International_Journal_Human_Resources_Development_and_Management_111_2011_1-15/ links/5640eed308ae24cd3e40ccdf/Walden-P-R-Bryan-VC-Rumlall-S2011-Informal-learning-in-the-workplace-a-comparison-of-two-modelsInternational-Journal-Human-Resources-Development-and-Management-111-2011-1-15.pdf

37. Winch, A., Ingram, H. (2002). Re-defining the focus of workplace learning. International Journal of Contemporary Hospitality Management, 14 (7), 361-367. Available at: https://www.emeraldinsight.com/doi/abs/10.1108/ 09596110210440666

38. Zhang, X., Bartol, K. M. (2017). Linking Empowering Leadership and Employee Creativity: The Influence of Psychological Empowerment, Intrinsic Motivation, and Creative Process Engagement. Academy of Management Journal, 53 (1), 107-128. Available at: https://journals.aom.org/doi/ abs/10.5465/AMJ.2010.48037118

\section{Acknowledgement}

This research is a part of the scientific project "Development of management in the entrepreneurial economy and society" supported by the University of Rijeka. 


\title{
RAZVOJ KARIJERE I UČENJE KAO DEMOTIVATORI U VELIKIM PODUZEĆIMA PRIMORSKO-GORANSKE ŽUPANIJE, HRVATSKA
}

\author{
Summary
}

U ovom su radu aspekti upravljanja ljudskim potencijalima: motivacija, upravljanje karijerom i upravljanje učenjem analizirani na uzorku najvećih poduzeća Primorsko-goranske županije. Upravljanje karijerom izučavano je kroz prizmu motivacije zaposlenika, s posebnim naglaskom na učenje koje bi zaposlenicima moglo osigurati dugoročnu zapošljivost na postojećem ili budućem radnom mjestu. Anketni upitnik je dizajniran na temelju pregleda literature te poslan elektroničkim putem na adrese 20 najvećih poduzeća Primorsko-goranske županije prema izvješću Hrvatske gospodarske komore, Županijske komore Rijeka. Iako je uzorak malen, što je temeljno ograničenje ovoga rada, istraživanje je ukazalo na negativne trendove u upravljanju ljudskim potencijalima. Usprkos drugačijim očekivanjima, rezultati su ukazali da velika poduzeća Primorsko-goranske županije imaju tek prosječno razvijene aktivnosti u sva tri istraživana aspekta upravljanja ljudskim potencijalima. Najveće iznenađenje predstavlja činjenica da menadžeri ispitanih poduzeća ispodprosječno posežu za nematerijalnim nagradama kojima se zaposlenicima izražava poštovanje za njihov rad, a koje su lako dostupne. Ta činjenica svakako pridonosi ispodprosječnom zadovoljstvu zaposlenika uvedenim programima motivacije i to prema mišljenju menadžera. Obećavajuća je činjenica da ispitana poduzeća ulažu iznadprosječne napore uvođenju novih programa učenja zbog značajnih promjena u svom poslovnom okruženju. Slaba i negativna korelacija između analiziranih konstrukata i poslovnoga rezultata ukazuje na produbljivanje postojećih problema i nepovoljne prognoze budućega razvoja ove županije. Nezadovoljstvo zaposlenika analiziranim aspektima upravljanja ljudskim potencijalima moglo bi još više pogoršati ionako dramatične trendove iseljavanja i odljeva mozgova iz Republike Hrvatske.

Ključne riječi: ljudski potencijali, motivacija, upravljanje karijerom, učenje 